\title{
EMPLOYMENT REGULATION PECULIARITIES IN THE TERMS OF LABOUR SHORTAGE
}

\section{N. Shaimardanov, N. Nekludova}

The article concerns today's challenges of employment as well as its regulation peculiarities, driven by increasing labour shortage. Taking into account negative impact of demographic factor, the authors offer priorities in regional employment regulation.

Demographic problems make the increasing impact on the sphere of labour activity, and, as a consequence, on prospects of economic development as a whole. In this connection the estimation of degree of the given influence, first of all, concerning employment restrictions in the regional economy is actual. For the definition of perspective labour force shortage in the region cumulative demand for labour (the sum of occupations and vacancies) was estimated on the functional dependence on GRP and the dynamics of capital accumulation. Calculations show that at the macro level, the factor of elasticity of cumulative demand for labour makes approximately $0,2 \%$ in GRP, and $(-0,1 \%)$ in capital resources.

On the basis of predictive variants of economy development of Sverdlovsk region till 2020 an estimation of perspective demand for labour (according to no-change, optimistic and innovative scenarios of development) had been made by the Institute of Economy of the Ural Branch of the Russian Academy of Sciences. Under the optimistic scenario the cumulative demand for labour in the region's economy increases with the average rate of $1 \%$ a year, under innovative $-0,6 \%$ a year, and under no-change scenario there is slight reduction in demand for labour. The growth of economics' requirement for labour was compared with the number of labour force. The result is interpreted as possible volume of labour offer which the regional economy can face in the nearest future. In this case migration was not taken into account.

According to the given estimation labour shortage in Sverdlovsk region will continue to increase. It will have reached, on the average (by 3 variants), from 150 thousand to 200 thousand people by the end of 2020. Despite the escalating of fixed capital and replacement of labour by the capital with the help of introduction of laborsaving technologies in the long term, nevertheless, labour shortage will be shown obviously enough. Realization of the $2 \mathrm{nd}$ and the 3rd scenarios will lead to earlier occurrence of labour shortage.
Expert estimations of the labour shortage reasons testify that there are five principal causes, along with demographic, in the basis of «personnel hunger». They are:

- low wage offered to applicants by employer;

- no possibility to give living to applicants;

- unwillingness of high school graduates to work by received profession;

- hard working conditions;

- insufficient quantity of the experts graduated from educational institutions of primary, secondary, or higher vocational level.

The problems arising in the sphere of employment and on the labour market define economic and social situation of the population and directly influence processes of its reproduction. So, unemployment makes negative impact on family development, defining its standard of living, the social status. Consequently, it is necessary to talk not only about an urgency of demographic problems in the context of labour market development, but also about importance of feedback. In their turn migrants make high enough demands to accepting territory.

It is possible to allocate the basic directions in construction of state regulation system of population employment with existing labour shortage and necessity to pursue immigration policy.

The basic possibilities to overcome the arising labour shortage are connected with increasing of economic activity and labour productivity, softening of structural problems of the labour market, replacing migration. We will consider the internal sources of softening of the revealed problem sharpness.

Increasing of economic activity of the population assumes, first of all, involving of a part of economically inactive population into the labour market. A separate problem is increasing of the age of retirement, as well as attraction of retired into the labour market.

Labour productivity increasing is substantially connected with increasing of capital-labour ratio. It demands (as the innovative scenario assumes) more intensive investments, first of all in the real sector of manufacture. The lack of them will strengthen branch heterogeneity of efficiency of labour force usage and, hence, aggravate the problem of its shortage. Currently the domestic economy lacks new, modern labour saving technologies. 
Necessary direction of preventive policy directed into softening of arising restriction of the labour offer in the economy is the solution of structural unemployment problem. In the opposite case economy will face the acute shortage of experts in variety of economy sectors and simultaneously a high rate of unemployment will be observed.

Thus overcoming of disproportions is a problem of, firstly, educational market (in the widest sense, including corporate courses and courses of retraining given by services of the population employment), secondly - internal migration (with the help of which structural disproportions on the labour market are eliminated, having geographical character) and thirdly - immigration.

In strategic prospect it is necessary to form the regional commission on studying and development of labour potential. Today, in a transition situation to economy of knowledge, not raw, but human resources become the key factor of economic development and pledge of competitiveness of the country in the XXI-st century.

The practical application of scientific results of researches in the field of demography, migrations, labour market and population employment in terms of working out and close agreement of employment and immigration policies, and also their embedding in the general context of regional social and economic development should become leading ideology of the given structure.

In the decision of the social problems the question is not so much about increasing of social obligations volume, as about working out of a new paradigm of the socially labour policy relied upon institutes of civil society, business and the state.

The following direction is the external source and the forecasting connected with it and planning of labour immigration which should be carried out in the context of the general immigration policy with accurately designated problems and the purposes. The great disadvantage the given direction, however, is the absence of Migration Policy Concept and, as a consequence, strategic reference points in sphere of labour migration. Migration Policy Concept being discussed since 2002 has not been adopted. Instead of it the Government adopted the Concept of Migration regulation in 2003. In the active Concept of Demographic Policy of the Russian Federation for the period till 2025 it is written that Demographic policy of the Russian Federation is designed to regulate internal and external migration [4]. That is it is a question of regulation problems exclusively. And even the reconstruction of the Governmental Commission on the Migration
Policy in 2009 testifies just only about the intention to have this policy.

It is possible to allocate concrete factors which can cause a choice of the purposes and means of an immigration policy:

- structural reforming of economy;

- influence of public opinion and interested lobbies;

- a geographical position;

- political situation, etc.

For the estimation of the region's supply with labour force and definition of economy's requirement for foreign labour it is necessary to carry out constant monitoring of economic and vocational structure of labour supply and demand on the market. The pursued policy should rely upon careful analysis of all available statistical material.

Creation and the correct organization of coordinating body becomes the major precondition of efficiency of employment policy. For the decision of problems connected with coordination of work between various competent bodies communication between immigration policies, mutual relations with the countries which are sources of immigration streams, policy of national safety maintenance, social policy, a policy of employment and in the education sphere, tax policy should be closer.

For example, Federal Migratory Service (FMS) assigned to the migratory sphere, has exclusively control functions.

Also it is necessary to pay attention to the fact that development of a state policy and its legal regulation concerns the competence of the Ministry of Internal Affairs in the field of migration [1], while corresponding powers in the field of labour migration are in the competence of Ministry of Health and Social Development of the Russian Federation [2].

Thus, the competence in the field of migration policy development is broken between the departments having different subordination; moreover, issues of migration regulation and labour migration regulation are artificially divided between specified departments. Besides, it is not visible from the documents regulating activity of Ministry of Health and Social Development and Federal Agency of Work and Employment what particularly the specified departments should do in the field of labour migration regulation.

The key problem is discrepancy of powers and institutional possibilities of the authorized department with the character of the migratory sphere itself.

The migratory policy is a function of a number of politics, being in higher layer of decision-making. 
On this basis the migratory function can be carried to different departments in the governmental system. Except for known variants, it can be in the structure of powers of the Ministry of regional development of the Russian Federation on the ground that regulation of migratory streams is function of a policy of regional development.

Today functions of the authorized state bodies in migration management sphere aren't built into the model of state labour market regulation. It should follow more particularly from the documents regulating activity of the corresponding executive brunch of the government, what functions are carried out by this or that department in the field of migration management since state activity as a regulator of labour market should be based on the accurate and clear to the market rules, be public and transparent.

Considering the aforesaid it is necessary to allocate following major directions at formation of the policy directed on closer interrelation of demographic, migratory processes and population employment:

1. Strengthening of interaction of the ministries and departments on coordination of actions in socially labour sphere. The Institute of Economy of Ural Brunch of the Russian Academy of Sciences carried out the analysis of the purposes, problems and functions of the seven ministries of Sverdlovsk region government activity of which influences, directly or indirectly, condition of socially labour sphere of the region. The analysis testifies the absence of coordination between them.

2. Working out of model of the scientificallyproved monitoring of the socially labour sphere including the analysis of the situation, control and the short-term forecast. It is impossible to make effective administrative decisions without well adjusted scientific system of monitoring. The given monitoring should be spent not only at region level, but also in a cut of municipal unions. For this purpose development of municipal statistics and formation of indicators both quantitative, and qualitative, characterizing processes in socially labour sphere, including migration.

For the monitoring carrying out it is reasonably to introduce outsourcing of functions on its realization. Monitoring should be spent by the independent organization with the assistance of scientistseconomists, demographers, sociologists, the lawyers well knowing region, feature of its development and with the interest and desire to help with the decision of problems.
3. Modernization of the population employment software in the modern conditions:

- working out of programs on the basis of regional strategy of development of employment for long-term prospect (10-15 years) taking into account territorial features of social and economic development;

- expansion of scope of application of regional programs of employment development on the process of reproduction of labour potential, unlike current practice when program regulation captures the population which addressed to employment service for consultation or job searching;

- working out of regional programs of temporary and permanent labour migration;

- introduction of the selective approach into the practice of labour migration regulation;

- division of labour migrants into categories (temporary, long-term and permanent constant) and carrying on a specialized policy of attraction, repatriation, adaptation and integration depending on the category

- the long time period of the action, allowing to estimate intermediate term and long-term social and economic effects of the programs;

- including in the programs of social and economic development of the region on the basis of the close agreement of the purposes, problems, priorities and mechanisms of realization of the policy of the population employment, the immigration policy with other directions of regional development;

- possibility within the limits of the programs to combine and unite efforts of all subjects of the population employment policy;

- establishment of quantitative parameters of productivity of programs by years of realization, with an annual estimation of actual results;

- constant system of monitoring, estimation and control over the course of realization of the programs.

4. Formation of constantly updated information base for the migratory planning, that will include:

- current condition and look-ahead (intermediate and long-term) estimations of demographic development of the region;

- current condition and look-ahead (intermediate and long-term) estimations of development of labour market and population employment by industries;

- formation of occupation shortage list (semiannual or quarterly);

- estimation of social and economic safety of region; 
- annual reviews of employers' requirement in labour;

- an estimation of efficiency of foreign labour usage.

\section{References}

1. RF President Edict No.1415 «Subjects of the Ministry of Internal Affairs of the Russian Federation» July, 31st, 2000 // Russian Federation Code. 2000. № 32. Article 3342.

2. RF Government Ordinance No. 321 «Concerning Ministry of Health and Social Development of the Russian Federation » June, 30, 2004. http://www.minzdravsoc.ru/docs/ government/postan/gov
3. RF Government Executive Order No. 256-p «Concerning Concept of migration regulation in the Russian Federation" March, 1st, 2003. http://www.ufmsoren.ru/Docs/PP/RaspP_ 256_01032003.htm

4. RF President Edict No.1351 «Concerning the Concept of Demographic Policy of the Russian Federation for the period till 2025» October, 9, 2007. http://www.ufms.spb.ru/desc/ ukazy-cid-16/

5. RF Government Ordinance No. 450 «Concerning Governmental Commission on the Migration Policy» May, 26, 2009. http://www.fms.gov.ru/images/newsimg/450.pdf

УДК 331.5

keywords: labour shortage, employment regulation, employment policy, immigration policy

\section{СОСТОЯНИЕ И ПЕРСПЕКТИВЫ ВОСПРОИЗВОДСТВА ТРУДОВЫХ РЕСУРСОВ В СЕВЕРНОМ РЕГИОНЕ}

В статье рассматриваются вопросы воспроизводства трудовых ресурсов в северном регионе на примере Ханты-Мансийского автономного округа - Югры. Сделан ретроспективный анализ и выполнены оценка состояния и прогноз трудовых ресурсов автономного округа.

Северные районы отличаются значительной дифференциацией воспроизводства населения и трудовых ресурсов. Особое место среди них занимает Ханты-Мансийский автономный округ - Югра (ХМАО-Югра), где демографические процессы, благодаря более молодой структуре населения по сравнению с другими регионами, носят позитивный характер. Здесь наблюдаются положительный естественный прирост и до настоящего времени положительное сальдо миграции. Высокий уровень жизни населения делает округ привлекательным для мигрантов как легальных, так и нелегальных. Значителен трудовой потенциал, в половозрастной структуре населения трудовые ресурсы составляют более $70 \%$. Тем не менее, диспропорции спроса и предложения рабочей силы на региональном рынке труда обусловили, с одной стороны, зна-

\footnotetext{
${ }^{1}$ Публикация выполнена в рамках Программы фундаментальных исследований Президиума РАН №24 Проект 09-П46-2001 «Разработка стратегии комплексного социальноэкономического освоения малоизученных и слабововлеченных в хозяйственный оборот территорий Уральского Севера».
}

чительную величину общей безработицы, с другой - привлечение рабочей силы из-за пределов автономного округа.

В 1990-е гг. начался процесс демографического старения населения ХМАО-Югры, продолжившийся и 2000-е гг. Он идет сразу в двух направлениях - «старение снизу» вследствие снижения рождаемости и «старение сверху», вызванное ростом числа пожилых и старых людей. В 2002 г. по данным переписи средний возраст населения составил 31,4 года, в 2009 г. - 33,6 года, или соответственно на 5,4 и 7,6 пунктов выше по сравнению с 1989 г.

В настоящее время население автономного округа заканчивает этап демографической молодости (доля лиц в возрасте 65 лет и старше ниже 4\%) и находится на пороге следующего этапа. Начальный этап старения населения округа характеризуется большей, по сравнению с показателями в целом по России, продолжительностью жизни населения; сравнительно низким уровнем смертности; высокой долей лиц трудоспособного возраста и др.

В 1990-е и 2000-е гг. в воспроизводстве населения главное место принадлежало естественному приросту, на долю которого в эти периоды пришлось соответственно 69,9 и 64,6\%, а в 2006-2009 гг. - 82\% общего прироста населения. Однако в обеспеченности трудовыми ресурсами значительную роль продолжает играть 
development of the Urals in the 19-20 centuries. Ekaterinburg 2000. 104 pp.

4. Population policies in the region: problems and prospects / [text]: sb. st. Under. Ed. Doctor of Sociology, prof. A. Kuzmin / Institute of Economics, UB RAS, 2010. 196.

5. Dmitriev A. V., Poduhov G. A. The receiving society: the practice of interaction with immigrants. // Sotsis. 2009. (№ 10)

6. Debt Victor. Have exhausted the quota // Rossiyskaya Gazeta. 2009. December 17 (№ 5066).

7. Rybakovsky L. L. Migration potential. Concept and criteria of evaluation. // Sotsis. 2009. (№ 2)
8. Rybakovsky L. L. Comparative evaluation of a demographic crisis of Russian regions // Sotsis. 2008. (№ 10)

9. Site Goskomstat of Russia [electronic resource]. URL: http://www.gks.ru.

10. Sverdlovsk Oblast Duma website [electronic resource]. URL: http://www.duma.midural.ru.

\section{U.D.C. 314.143 (1)}

keywords: migration, population, migration gain, migration dynamics, migration links 